Gut, 1980, 21, 675-682

\title{
Lymphocyte subpopulations of intestinal mucosa in inflammatory bowel disease
}

\author{
O E EADE,* S ST ANDRE-UKENA, C MOULTON, B MACPHERSON, AND \\ W L BEEKEN
}

From the Departments of Medicine and Pathology, University of Vermont College of Medicine, Burlington, Vermont 05405, USA

SUMmARY Lymphocyte subpopulations in peripheral blood (PBL) and intestinal mucosa (IML) of 10 patients with inflammatory bowel disease (IBD) were compared with those of 11 non-IBD controls. PBL were separated on Ficoll/Hypaque gradients, and IML were isolated by incubations in dithiothreitol, EDTA, and collagenase. These methods yielded cells of good viability and with intact HLA A and B-antigens. T-cells, identified by neuraminidase-treated sheep RBC rosettes and non-specific esterase staining, comprised approximately $91 \%$ of the IML from normal mucosa of all groups. B-cells, identified by erythrocyte-antibody-complement rosettes and surface immunoglobulins, were only $7 \%$ of these IML populations. Cell yields were two-fold or more greater from abnormal IBD mucosa, with T-cells ranging from 55 to $95 \%$ and B-cells from 2 to $36 \%$. The percentage of $\mathrm{Fc}$ receptor bearing cells was low in all specimens. By these methods, T-lymphocytes predominated in intestinal mucosa of both IBD and non-IBD patients, but there is marked increase in the percentage of B-cells isolated from abnormal mucosa in IBD.

There is a growing body of evidence that lymphocytes play an important role in the pathogenesis of inflammatory bowel disease (IBD). Most studies supporting such a role have been conducted with peripheral blood lymphocytes, whereas the most important site of immunological reaction is likely to be in the gut itself. Accordingly, it is appropriate to define the subpopulations of intestinal lymphocytes and to investigate their role in the inflammatory response of IBD and other disorders.

Intestinal lymphocyte populations have been enumerated by immunofluorescent studies of frozen tissue sections and by the study of purified lymphoid cells isolated from intestinal resections. Immunofluorescent studies of frozen sections indicate a predominance of T-cells in epithelium and lamina propria in normal tissue and in unaffected bowel from patients with Crohn's disease but a preponderance of B-cells in all but the epithelial layer in areas of IBD..$^{1-4}$ These studies yielded semiquantitative results because precise morphological interpretation is difficult and a variable loss of diffusable immunoglobulin occurs in frozen sections. ${ }^{5}$

Address for reprint requests: W L Beeken, MD, C311, Given Building, University of Vermont, Burlington, Vermont, USA 05405.

*Present address: Professorial Medical Unit, Level F, Centre Block, Southampton General Hospital, Southampton SO9 4XY, England.

Received for publication 26 February 1980
Recently, methods have been described for isolating lymphocytes from intestinal resections which permit more precise identification and quantification. ${ }^{6-12}$ In studies of IBD, ileal $\mathrm{T}$ lymphocytes have ranged from $63 \%$ to $68 \cdot 5 \%$ compared with $35.4 \%$ to $83 \%$ for controls, and affected colonic tissue contained $49 \%$ T-cells compared with $64 \%$ T-lymphocytes in controls. ${ }^{13}{ }^{14} \mathrm{~B}$-cell populations were reciprocally increased in diseased tissue from both ileum and colon.

In the present study, we have examined subpopulations of lamina propria lymphocytes from patients with IBD and other disorders using both a stabilised erythrocyte rosetting technique and alpha-naphthyl acetate esterase staining to identify T-cells. Surface immunoglobulin and formation of erythrocyte-IgM antibody-complement rosettes (EAC) were used to identify B-cells, and erythrocyte-antibody (EA) rosettes to identify $\mathrm{Fc}$ receptor bearing cells. We found a higher percentage of T-cells than previously reported in both normal and diseased mucosa, and a variable increase in B-lymphocytes in affected tissue.

\section{Methods}

PATIENTS AND SPECIMENS

Ten patients with IBD (seven Crohn's disease and three ulcerative colitis) and 11 non-IBD controls 
Table 1 Patient data and histopathology of specimens studied

\begin{tabular}{|c|c|c|c|c|c|c|c|}
\hline \multirow{3}{*}{$\begin{array}{l}\text { Patient no. } \\
\text { and diagnosis }\end{array}$} & & \multirow{3}{*}{$\begin{array}{l}\text { Age } \\
(y r)\end{array}$} & \multirow[t]{3}{*}{$\operatorname{Sex}$} & \multicolumn{4}{|c|}{ Specimen-Histology } \\
\hline & & & & \multicolumn{2}{|l|}{ Ileum } & \multicolumn{2}{|l|}{ Colon } \\
\hline & & & & Normal & Abnormal & Normal & Abnormal \\
\hline \multicolumn{8}{|l|}{ IBD } \\
\hline \multirow[t]{6}{*}{ Crohn's disease } & 1 & 30 & $\mathbf{M}$ & + & & & + \\
\hline & 2 & 30 & $\mathbf{F}$ & + & + & & $r$ \\
\hline & 3 & 23 & $\mathbf{M}$ & & + & & \\
\hline & 4 & 24 & $\mathbf{F}$ & & + & & \\
\hline & 5 & 41 & $\mathbf{M}$ & & + & + & \\
\hline & 6 & 29 & $\mathbf{F}$ & & & & + \\
\hline \multirow{5}{*}{$\begin{array}{l}\text { Ulcerative } \\
\text { colitis }\end{array}$} & & & & & & & \\
\hline & 7 & 24 & $\mathbf{M}$ & & & & + \\
\hline & 8 & 73 & $\mathbf{M}$ & & & & + \\
\hline & 9 & 28 & $\mathbf{F}$ & & & & + \\
\hline & 10 & 19 & $\mathbf{F}$ & + & & & + \\
\hline \multirow{2}{*}{\multicolumn{8}{|c|}{$\begin{array}{l}\text { Non-IBD } \\
\text { Large bowel }\end{array}$}} \\
\hline & & & & & & & \\
\hline \multirow{8}{*}{ cancer } & 2 & 50 & M & & & $\dot{\dot{t}}$ & \\
\hline & 3 & 56 & $F$ & & & + & \\
\hline & 4 & 57 & $\mathrm{~F}$ & & & + & \\
\hline & 5 & 68 & $\mathrm{~F}$ & & & + & \\
\hline & 6 & 75 & $\mathrm{~F}$ & & & + & \\
\hline & 7 & 76 & $\mathrm{~F}$ & & & + & \\
\hline & 8 & 81 & $\mathrm{~F}$ & & & + & \\
\hline & 9 & 64 & $\mathbf{M}$ & & & + & \\
\hline \multirow{3}{*}{$\begin{array}{c}\text { Cancer of } \\
\text { bladder } \\
\text { Neurogenic } \\
\text { bladder }\end{array}$} & & & & & & & \\
\hline & 10 & 48 & $\mathbf{M}$ & + & & & \\
\hline & 11 & 38 & $\mathbf{F}$ & + & & & \\
\hline
\end{tabular}

(nine of whom had colorectal cancer) were studied (Table 1). Indications for resection in IBD patients were obstruction in three and intractable disease in the remaining seven, including relentless perianal disease in one, and perforation in another. All were taking steroids shortly before or at the time of operation. Intestinal resections were obtained immediately after surgical removal. Specimens measuring approximately $2 \times 4 \mathrm{~cm}$ were placed directly into Eagle's Minimal Essential medium (MEM) containing $10 \%$ fetal calf serum (FCS), penicillin $(10000 \mathrm{U} / \mathrm{ml})$, streptomycin $(10000 \mu \mathrm{g} / \mathrm{ml})$, and chlortetracycline $(5000 \mu \mathrm{g} / \mathrm{ml})$. Specimens were examined by light microscopy and the histopathology from each patient is indicated in Table 1.

\section{PERIPHERAL BLOOD LYMPHOCYTE}

ISOLATION (PBL)

Lymphocytes were separated from heparinised blood on a Ficoll-Hypaque (LSM, Litton Bionetics, Kensington, Md.) density gradient. ${ }^{15}$

INTESTINAL MUCOSAL LYMPHOCYTE ISOLATION (IML)

A modification of the method of Bull and Bookman ${ }^{10}$ was used. The mucosa was dissected from muscularis and washed in Hank's balanced salt solution, immersed in $1 \mathrm{mM}$ dithiothreitol (DTT) for 10 minutes and then in calcium-magnesium free Hank's balanced salt solution. The washed pieces were incubated in
$0.75 \mathrm{mM}$ ethylene-diaminotetracetate (EDTA) for two 90 minute periods to remove surface epithelial cells. The exposed lamina propria was then incubated in type IV collagenase (Sigma Chemical Co, St Louis, Mo, Lot 55C 6810), $0.075 \mathrm{mg} / \mathrm{ml} \mathrm{MEM}$ at $37^{\circ} \mathrm{C}$ with gentle stirring overnight. The lymphocyte suspension was washed twice and postcollagenase digestion debris was removed by filtration through a stainless steel wire mesh (300 size). The lymphocytes were separated by Ficoll-Hypaque density gradient and resuspended in Eagle's Minimal Essential medium fetal calf serum.

\section{VIABILITY TESTING AND COUNTING}

Viability was assessed by complete exclusion of $0.4 \%$ trypan blue. Lymphocytes were counted in a haemacytometer, monocytes being excluded by size and morphology.

\section{T CELL IDENTIFICATION}

Neuraminidase-treated sheep erythrocyte (EN) rosettes $^{16}$

Washed sheep erythrocytes (Becton Dickinson \& Co., Cockeysville, Md) were incubated with neuraminidase (Sigma), $0 \cdot 16 \mu / \mathrm{ml}$ final concentration, for 40 minutes at $37^{\circ} \mathrm{C}$. After incubation, the erythrocytes were washed three times with Hank's balanced salt solution and kept at $4^{\circ} \mathrm{C}$ until used. Lymphocytes were incubated with neuraminidase-treated erythrocytes at $37^{\circ} \mathrm{C}$ for 15 minutes, centrifuged at 
$50 \mathrm{~g}$ for 10 minutes, chilled for 20 minutes, and incubated overnight at $4^{\circ} \mathrm{C}$. Cells were gently resuspended to avoid disrupting the rosettes, stained with $0.1 \%$ toluidine blue in $90 \%$ methanol, and the percentage of rosetting lymphocytes determined by counting 200 cells.

Alpha-naphthyl acetate esterase activity $(A N A E)^{17}$ Cytocentrifuge (Shandon-Southern Instruments, Inc, Sewickly, Pa) preparations were made from resuspensions of the neuraminidase-treated sheep erythrocyte pellets. Slides were air dried for at least two hours and stained with ANAE in pararosaniline and sodium nitrite (Sigma) by overnight incubation. Slides were counterstained with $1 \%$ methyl green or $1 \%$ toluidine blue and examined for ANAE staining.

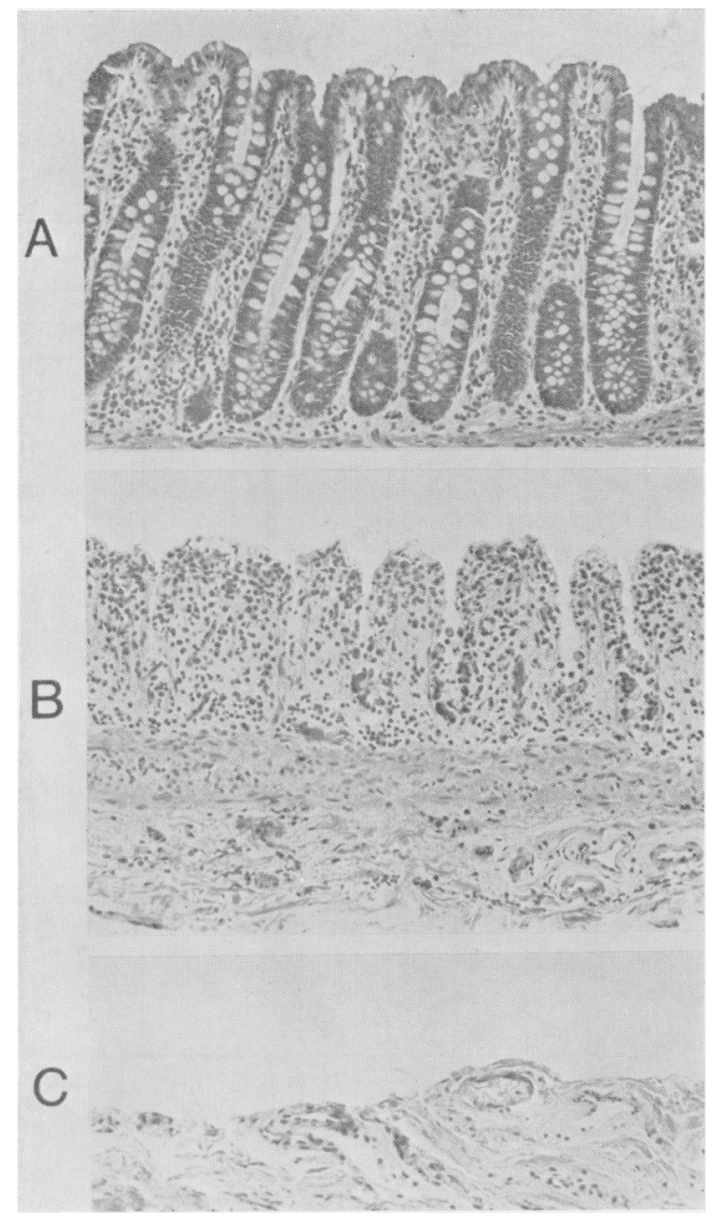

Fig. 1 A. Colonic mucosa after dithiothreitol treatment. $B$. Colonic mucosa with epithelium stripped by incubation in EDTA. C. Muscularis after denudation of lamina propria by collagenase (original magnification $\times 100$ ).
B CELL IDENTIFICATION

EAC rosettes ${ }^{18}$

To identify C3 receptor bearing lymphocytes, rosettes were prepared with sheep erythrocytes coated with a 1:75 dilution of IgM antibody (Cordis Laboratories, Miami, Fla). Fresh frozen mouse serum was used as the source of complement. Incubations were for 30 minutes at $37^{\circ} \mathrm{C}$. Rosettes forming without addition of complement (E IgM) and with uncoated sheep erythrocytes (EU) served as controls.

\section{Surface immunoglobulins}

Surface immunoglobulins were detected using fluoresceinated antihuman polyvalent goat immunoglobulin with high fluorescein to protein ratio (Meloy Laboratories Inc, Springfield, Va). $4 \times 10^{5}$ lymphocytes were incubated with $0.1 \mathrm{ml}$ of a $1: 2.5$ dilution of fluoresceinated immunoglobulin for 45 minutes at $4^{\circ} \mathrm{C}$, resuspended in $1 \mathrm{ml}$ Hank's balanced salt solution, centrifuged at $50 \mathrm{~g}$ for 10 minutes, resuspended in equal volumes of HBSS-2\% paraformaldehyde in PBS for 15 minutes in the dark, centrifuged at $50 \mathrm{~g}$ for 10 minutes, and resuspended in PBS. Cells were centrifuged again and examined for surface fluorescence with a Leitz-Wetzlar fluorescence microscope fitted with an HBO 200 mercury vapor lamp.

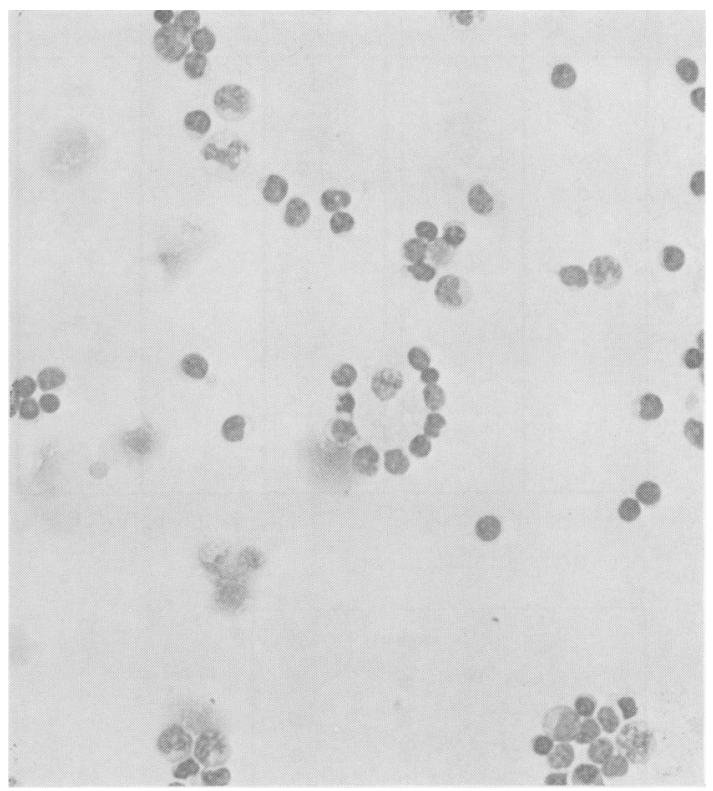

Fig. 2 Cytospin preparation of lamina propria mononuclear cells (original magnification $\times 250$ ). 


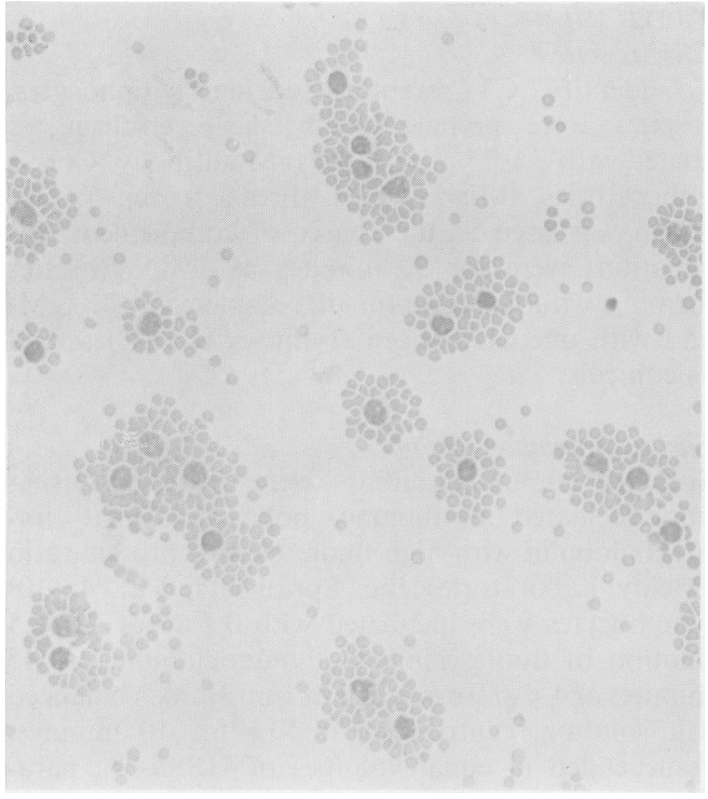

Fig. 3 EN rosettes of intestinal mucosa lymphocytes (original magnification $\times 250$ ).

EN
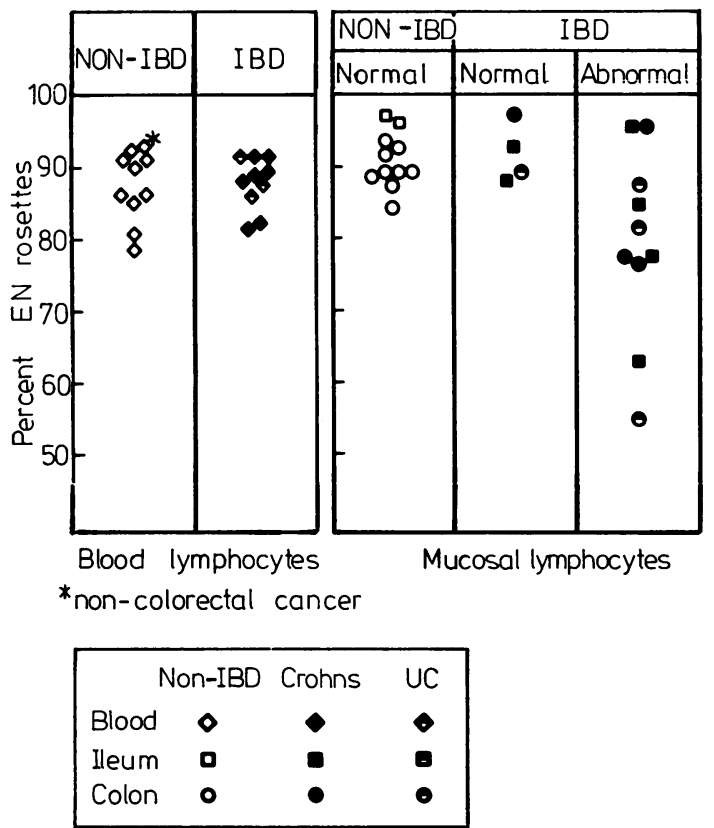

Fig. 4 Percentages of lymphocytes from blood and normal and diseased intestinal mucosa identified as $T$-cells by EN rosette formation.
EA ROSETTES

To identify Fc receptor bearing lymphocytes, rosettes were prepared by incubation with sheep erythrocytes coated with $7 \mathrm{~S}$ (IgG) antibody (Cordis Labs.) at a 1:600 dilution for 30 minutes at $21^{\circ} \mathrm{C}$.

\section{HISTOCOMPATIBILITY ANTIGEN}

TESTING (HLA)

To further test the surface integrity of intestinal mucosal lymphocytes, HLA antigens were deter-

Table $2 H L A$ antigens of intestinal mucosa lymphocytes (IML) and peripheral blood lymphocytes ( $P B L)$ from five additional patients undergoing bowel resection

\begin{tabular}{llll}
\hline Patient & & A Locus & B Locus \\
\hline 1 & IML & $2, \mathrm{~W} 24$ & $5,7$. \\
& PBL & $2, \mathrm{~W} 24$ & $5,7$. \\
2 & IML & 3,11 & W35, - \\
3 & PBL & 3,11 & W35, - \\
& IML & 3,29 & 7,17 \\
4 & PBL & 3,29 & 7,17 \\
5 & IML & 1,3 & 5,15 \\
& PBL & 1,3 & 5,15 \\
& IML & 1, W24 & 5,12 \\
& PBL & 1, W24 & 5,12 \\
\hline
\end{tabular}

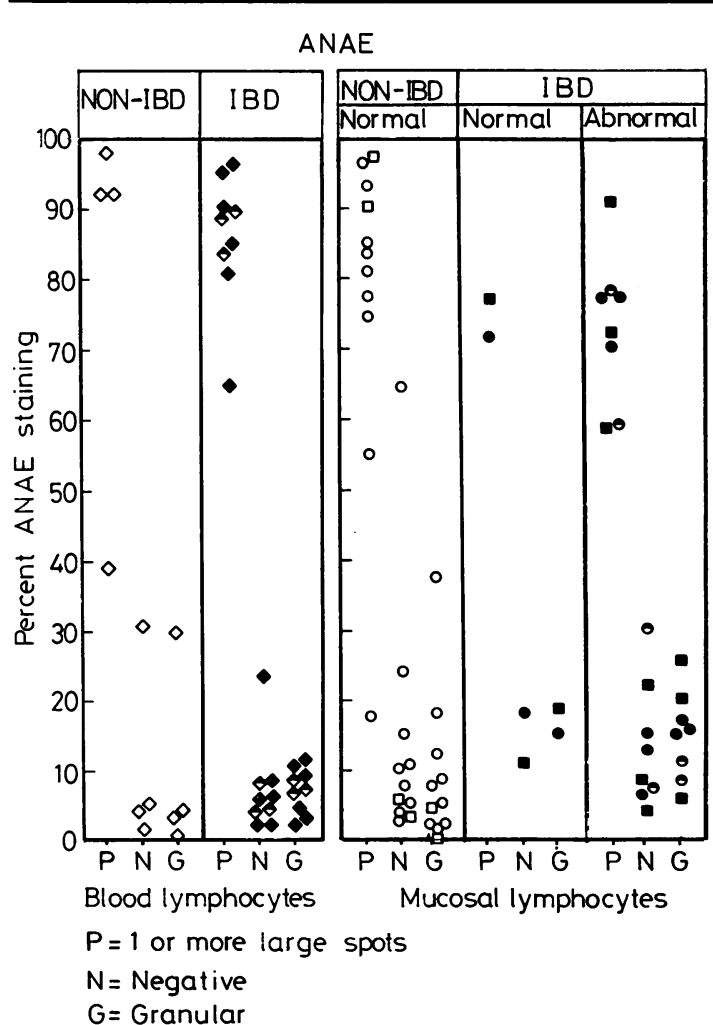

Fig. 5 Alpha naphthyl acetate esterase staining of lymphocytes of blood and normal and diseased intestinal mucosa. Symbols as in Fig. 4. 


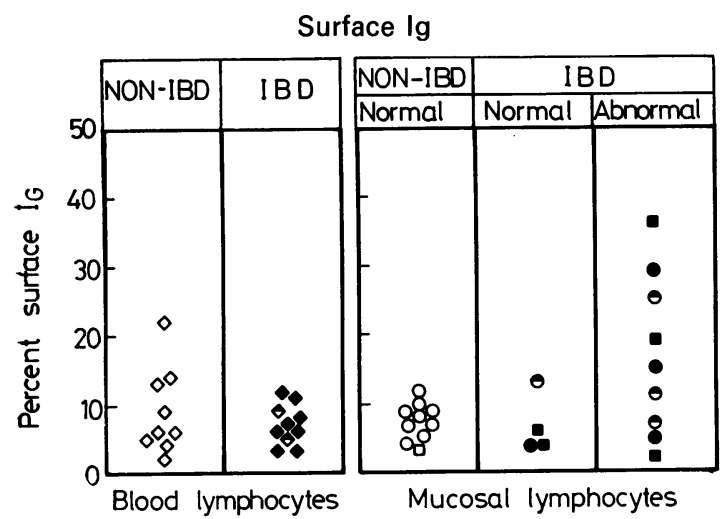

Fig. 6 Percentages of B-lymphocytes identified by surface immunoglobulin in blood and normal and diseased intestinal mucosa. Symbols as in Fig. 4.

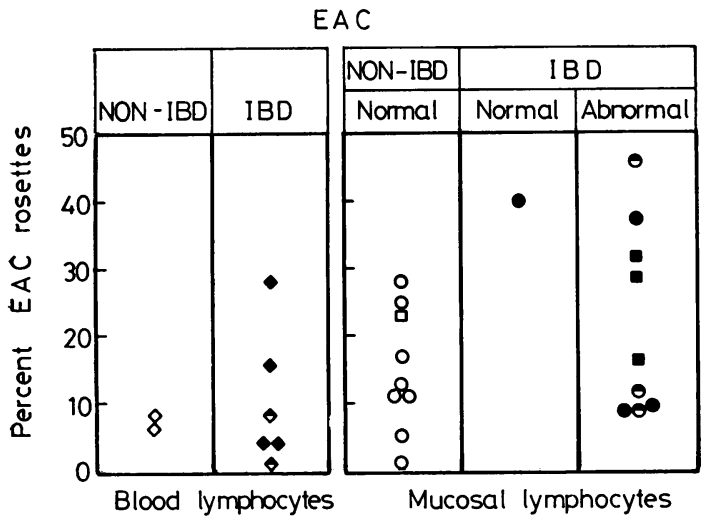

Fig. 7 Percentages of blood and mucosal lymphocytes demonstrating erythrocyte-antibody-complement rosetting. Symbols as in Fig. 4.

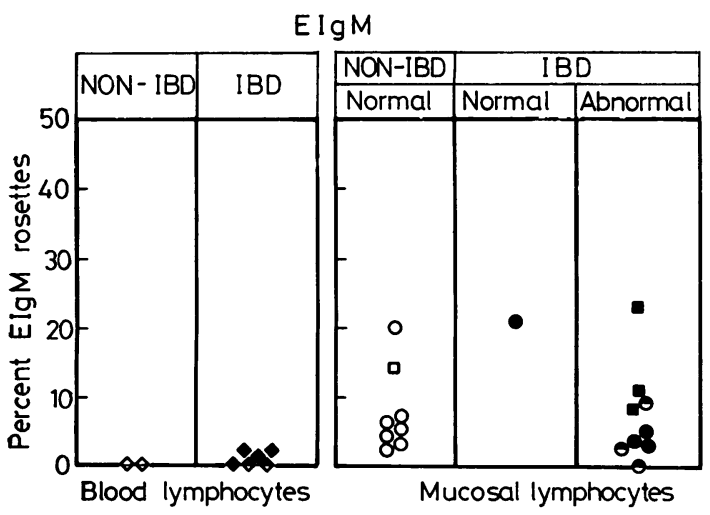

Fig. 8 Percentages of blood and mucosal lymphocytes rosetting in the presence of erythrocytes and antibody (E IgM) without complement. Symbols as in Fig. 4. mined on peripheral blood lymphocytes and corresponding IML from five additional patients by the Amos modification of the microlymphocytotoxicity technique. ${ }^{19}$

\section{Results}

The histology of an intestinal specimen at various stages in the isolation procedure is shown in Fig. 1 and a cytospin preparation of isolated lamina propria mononuclear cells is shown in Fig. 2. The total numbers of IML isolated from 2 to $8 \mathrm{~g}$ of tissue varied from 2 to $200 \times 10^{6}$ and tended to be higher with inflamed mucosa. Mean viabilities exceeded $90 \%$. The HLA antigens in 5 IML suspensions were identical to those of the mucosal lymphocytes (Table 2). Macrophages, plasma cells, mast cells, eosinophils, neutrophils, and epithelial cells were seen in small numbers, as were naked nuclei and other tissue debris.

Percentages of $T, B$ and $F c$ receptor bearing lymphocytes identified in intestinal mucosal preparations are shown in Figs. 4-10. In normal tissue from IBD and non-IBD resections, T-lymphocytes predominated, averaging $91.6 \%$ and $90.6 \%$ respectively by the EN rosetting technique (Figs. 3 and 4). The less specific ANAE staining results supported this finding (Fig. 5). Correspondingly low numbers of B-cells were identified in the IBD and non-IBD specimens by SIg, 6.8\% and $7 \cdot 4 \%$ respectively (Fig. 6). The slightly higher percentages of EAC rosetting lymphocytes (Fig. 7) are explained in part by non-specific rosetting in control tests (EIgM and EU) seen with IML (Figs. 8 and 9). Percentages of lymphocytes with $\mathrm{Fc}$ receptors were uniformly low (Fig. 10).

In abnormal IBD tissue, T-lymphocytes also pre-

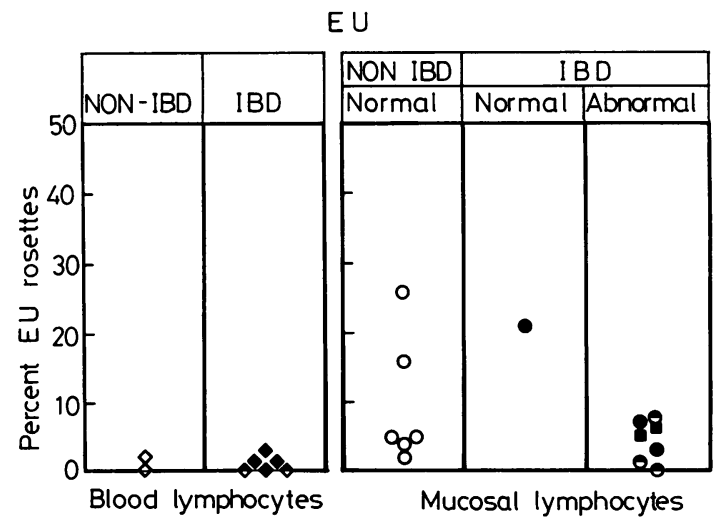

Fig. 9 Percentages of blood and mucosal lymphocytes rosetting with erythrocytes not coated with $\operatorname{IgM}(E U)$. Symbols as in Fig. 4. 


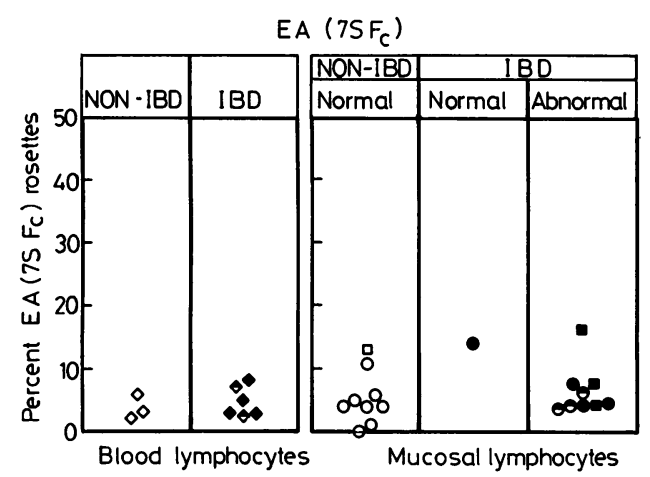

Fig. 10 Percentages of blood and mucosal lymphocytes demonstrating Fc receptors. Symbols as in Fig. 4.

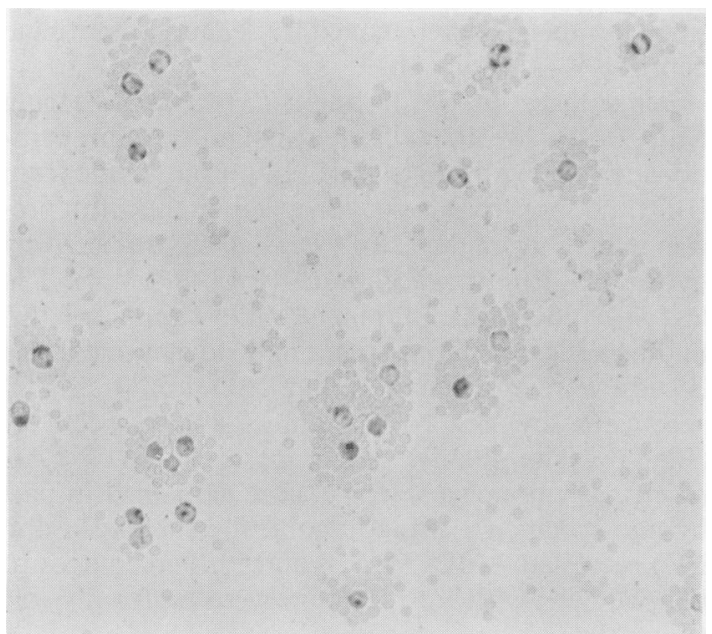

Fig. 11 Patterns of alpha naphthyl acetate (ANAE) esterase staining observed in mucosal lymphocyte preparations - that is, one or two spots-granular (original magnification $\times 250$ ).

dominated, but the percentages were more variable. T-cells identified by $\mathrm{EN}$ rosetting ranged from $54.5 \%$ to $95 \%$, with B-cell percentages ranging from $2 \%$ to $36 \%$ by the SIg technique. Cell yields were usually higher from diseased areas compared with normal regions. In one case of Crohn's disease, percentages in the muscular layers were similar to those in mucosa.

The majority of IML were ANAE positive, the predominant pattern being one or two darkly staining spots as with PBL (Fig. 11). Some lymphocytes contained finer, more numerous granules, and macrophages stained diffusely. No major staining differences were observed between IML from inflamed and non-inflamed gut from IBD patients. Unfortunately, ANAE preparations were not available from the IBD patient showing the most striking increase in B-lymphocytes in the region of disease. Two patients with colon cancer demonstrated greater numbers of cells which either stained with a granular pattern or were ANAE negative. In both instances, the percentage of EN rosetting cells in IML preparations exceeded $80 \%$ (Fig. 5).

\section{Discussion}

The high T-lymphocyte counts observed with EN rosetting were supported by ANAE positive cells in IML suspensions and the fact that B-lymphocyte counts were correspondingly low. The percentages of both populations were similar to those seen in peripheral blood. As in the present study, Bull and Bookman ${ }^{10}$ found that the percentage of T-cells in peripheral blood was similar to that in intestinal mucosa. PBL-IML comparisons were not reported by Goodacre et al..$^{12}$ The preparations of T- and B-cells in our study differed somewhat from those of other studies. Breucha et al. ${ }^{20}$ found $30-60 \%$ $\mathrm{T}$-cells in small intestinal and appendiceal specimens. Bull and Bookman ${ }^{10}$ found a mean of $64 \%$ T-cells in colon using the $\mathrm{E}$ rosetting method of Jondal et al. $^{21}$ and $36 \%$ B-cells by SIg. Goodacre et al. ${ }^{12}$ reported $38 \%$ T-cells identified by $E$ rosettes. These studies, however, did not use rosettes stabilised with neuraminidase or 2-aminoethyl isothiouronium bromide (AET). Such stabilisation appears to be essential for detecting the total T-cell population..$^{22}$

Numerous studies document ANAE staining of T-cells. ${ }^{23-30}$ In the present study, the majority of ANAE positive IML showed at least one dense localised spot of ANAE activity, the pattern most often observed with T-cells in the previous studies. Macrophages are also ANAE positive, but are readily distinguished from lymphocytes morphologically and by their diffuse staining pattern. The literature suggests that helper T-lymphocytes with Fc receptors for IgM (TM-cells) stain with one or two large spots, whereas suppressor T-cells with IgG Fc receptors (TG-cells) either do not stain or stain with a granular pattern. ${ }^{27}{ }^{30}$ In two cases of colon cancer, the percentage of T-cells showing single spot staining was low, suggesting that the number of helper cells was diminished and that suppressor cells were increased.

It is theoretically possible that our high percentage of T-cells was due to a selective loss of B-lymphocytes during FH separation. However, when the cells sedimenting through the $\mathrm{FH}$ gradient were examined, only a few lymphocytes were found and they had the same proportion of EN rosetting cells as those from the interface. Conceivably, B-lymphocytes could be more fragile and disrupt 
during the isolation procedure, but we know of no evidence for this. In fact, studies have shown that the FH separation technique is non-selective for PBL. ${ }^{31}$ A third possible explanation for our finding of low B-lymphocyte numbers in IML suspensions might be that B-lymphocytes of the gut rapidly differentiate into plasma cells. We have not enumerated plasma cells. Although plasma cells identified on morphological grounds were present in only small numbers as previously observed, they were present in somewhat greater numbers in the FH separation pellet. Naked plasma cell nuclei were sometimes observed, indicating that some disruption had occurred.

We found no evidence of a large null cell population in the human gut mucosa and here, our findings are in agreement with those of Bull and Bookman. ${ }^{10} 14$ Moreover, the low percentages of IgG Fc receptor bearing cells, which included the K-cells, are compatible with the absence of ADCC as reported by some investigators for guinea-pig ${ }^{32}$ and human ${ }^{1114}$ intestinal lymphocyte preparations.

There were no consistent differences between IML from ileum and colon. Although results for T and B IML from IBD patients were variable, there was a tendency towards higher B-cell counts in inflamed tissue. This is in agreement with the results of Meijer, Bosman, and Lindeman ${ }^{4}$ and Bookman and Bull. ${ }^{14}$ In one case, we were unable to confirm any major differences in subpopulations of lymphocytes derived from mucosa from deeper layers, a finding which contrasts with the results of others. ${ }^{13}$ Furthermore, there were no consistent differences between IML from patients with Crohn's disease and those with ulcerative colitis.

In conclusion, we found a striking predominance of T-lymphocytes in preparations from histologically normal human intestinal mucosa. Although there was a tendency for the B-cell population to increase in inflamed tissue of patients with IBD, T-lymphocytes remained the predominant cell type. Additional functional studies of IML from patients with IBD will be required to identify any specific role for mucosal lymphocytes in the pathogenesis of this disorder.

\section{References}

${ }^{1}$ Strickland RG, Husby G, Black WC, Williams RC Jr. Peripheral blood and intestinal lymphocyte subpopulations in Crohn's disease. Gut 1975; 16: 847-53. ${ }^{2}$ Baklien K, Brandtzaeg P. Comparative mapping of the local distribution of immunoglobulin-containing cells in ulcerative colitis and Crohn's disease of the colon. Clin Exp Immunol 1975; 22 : 197-209.

${ }^{3}$ Meuwissen SGM, Feltkamp-Vroom TM, Brutel De la Rivière $\mathrm{A}$, Von dem Borne AEGKr, Tytgat GN.
Analysis of the lympho-plasmacytic infiltrate in Crohn's disease with special reference to identification of lymphocyte-subpopulations. Gut 1976; 17: 770-80.

${ }^{4}$ Meijer CJLM, Bosman FT, Lindeman J. Evidence for predominant involvement of the B-cell system in the inflammatory process in Crohn's disease. Scand $J$ Gastroenterol 1979; 14: 21-32.

${ }^{5}$ Brandtzaeg $\mathrm{P}$, Baklien $\mathrm{K}$. Immunohistochemical studies of the formation and epithelial transport of immunoglobulins in normal and diseased human intestinal mucosa. Scand J Gastroenterol 1976; 11 suppl 36: 1-45.

${ }^{6} \mathrm{Rudzik} \mathrm{O}$, Bienenstock J. Isolation and characteristics of gut mucosal lymphocytes. Lab Invest 1974; 30: 260-6.

${ }^{7}$ Mavligit GM, Jubert AV, Gutterman JU, McBride CM, Hersh EM. Immune reactivity of lymphoid tissues adjacent to carcinoma of the ascending colon. Surg, Gynecol \& Obstet 1974; 139: 409-12.

${ }^{8}$ Breucha G, Riethmüller G, Rieber EP. Isolierung und immunologische Charakterisierung von Lymphocyten aus humanen Appendices. Klin Wochenschr 1975; 53: 1155-9.

${ }^{9}$ Clancy R. Isolation and kinetic characteristics of mucosal lymphocytes in Crohn's disease. Gastroenterology 1976; 70: 177-80.

${ }^{10}$ Bull DM, Bookman MA. Isolation and functional characterization of human intestinal mucosal lymphoid cells. J Clin Invest 1977; 59: 966-74.

${ }^{11}$ Clancy R, Pucci A. Absence of K-cells in human gut mucosa. Gut 1976; 19: 273-6.

${ }^{12}$ Goodacre R, Davidson R, Singal D, Bienenstock J. Morphologic and functional characteristics of human intestinal lymphoid cells isolated by a mechanical technique. Gastroenterology 1979; 76: 300-8.

${ }^{13}$ Breucha $G$, Riethmüller G. Intestinal lymphocytes in Crohn's disease (letter). Lancet 1975; 1: 976.

${ }^{14}$ Bookman MA, Bull DM. Characteristics of isolated intestinal mucosal lymphoid cells in inflammatory bowel disease. Gastroenterology 1979; 77: 503-10.

${ }^{15}$ Boyum A. Isolation of lymphocytes, granulocytes and macrophages. Scand J Immunol 1976; 5 suppl 5: 9-15.

${ }^{16}$ Weiner MS, Bianco C, Nussenzweig V. Enhanced binding of neuraminidase-treated sheep erythrocytes to human T lymphocytes. Blood 1973; 42: 939-46.

${ }^{17} \mathrm{Li} \mathrm{CY}$, Yam LT, Crosby WH. Histochemical characterization of cellular and structural elements of the human spleen. J Histochem Cytochem 1972; 20: 1049-58.

${ }^{18}$ Shevach EM, Herberman R, Frank MM, Green I. Receptors for complement and immunoglobulin on human leukemic cells and human lymphoblastoid cell lines. J Clin Invest 1972; 51 : 1933-8.

${ }^{19}$ Amos DB, Bashir H, Boyle W, MacQueen $M$, Tiilikainen A. A simple microcytotoxicity test. Transplantation 1969; 7 : 220-3.

${ }^{20}$ Breucha G, Rieber EP, Riethmüller G. Characterization of lymphocytes isolated from human small intestine (abstract). Eur Surg Res 1974; 6 suppl 1: 38.

${ }^{21}$ Jondal M, Holm G, Wigzell H. Surface markers on human $\mathrm{T}$ and $\mathrm{B}$ lymphocytes. 1. A large population of lymphocytes forming non-immune rosettes with sheep red blood cells. J Exp Med 1972; 136: 205-15. 
${ }^{22}$ Gelfand EW, Shore A, Green B, Lin MT, Dosch HM. The E-rosette assay: a cautionary note. Clin Immunol Immunopathol 1979; 12: 119-23.

${ }^{23}$ Mueller J, Brun del Re G, Buerki H, Keller HU, Hess MW, Cottier H. Non-specific acid esterase activity: a criterion for differentiation of $\mathrm{T}$ and $\mathrm{B}$ lymphocytes in mouse lymph nodes. Eur J Immunol 1975; 5: 270-4.

${ }^{24}$ Ranki A, Tötterman TH, Häyry P. Identification of mouse $\mathrm{T}$ and $\mathrm{B}$ lymphocytes from cytocentrifuged cell smears. Clin Exp Immunol 1976; 26: 632-40.

${ }^{25}$ Kulenkampff J, Janossy G, Greaves MF. Acid esterase in human lymphoid cells and leukaemic blasts: a marker for T lymphocytes. Br J Haematol 1977; 36: 231-40.

${ }^{26}$ Horwitz DA, Allison AC, Ward P, Kight N. Identification of human mononuclear leukocyte populations by esterase staining. Clin Exp Immunol 1977; 30: $289-98$.

${ }^{27}$ Grossi CE, Webb SR, Zicca A, et al. Morphological and histochemical analyses of two human T-cell subpopulations bearing receptors for IgM or IgG. J Exp Med 1978; 147: 1405-17.
${ }^{28}$ Obrist R, Albrecht R, Nagel GA. Identification of lymphocyte subpopulations by simultaneous E-rosette formation and unspecific acid esterase staining. $E x$ perientia 1978; 34: 660-1.

${ }^{29}$ Barr RD, Allardyce M. Cytochemical identification of human T-lymphocytes. Can Med Assoc J 1978; 118: 1279-85.

${ }^{30}$ Manconi PE, Marrosu MG, Paghi L, Correale G, Zaccheo D. Alpha naphthyl acetate esterase activity in human lymphocytes: distribution in lymnphocyte subpopulations and in mitogen-activated cells. Scand J Immunol 1979; 9: 99-104.

${ }^{31}$ Chess L, Schlossman SF. Methods for the separation of unique human lymphocyte subpopulations. In: Rose NR, Friedman H, eds. Manual of clinical immunology. Washington DC: American Society for Microbiology, 1976: 77-80.

${ }^{32}$ Arnaud-Battandier F, Bundy BM, O'Neill M, Bienenstock J, Nelson DL. Cytotoxic activities of gut mucosal lymphoid cells in guinea pigs. $J$ Immunol 1978; 121: 1059-65. 